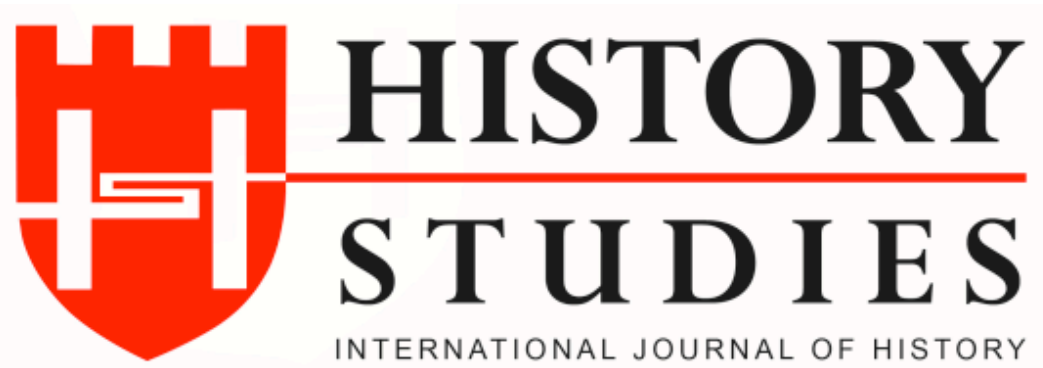

ISSN: 13094173 (Online) 1309 - 4688 (Print)

Volume 9 Issue 4, p. 183-202, November 2017

DOI: $10.9737 /$ hist.2017.556

\title{
Osmanlı Diplomatiğinde Mühür ve Bir Vaka Olarak Sahte Mühür Kullanımı
}

\author{
Seal in Ottoman Diplomacy and Use of Fake Seal As A Case \\ Yrd. Doç. Dr. M. Yasin TAŞKESENLİOĞLU \\ (ORCID: 0000-0003-2635-829X) \\ Bayburt Üniversitesi - Bayburt
}

\begin{abstract}
Öz: Bu çalışmada Osmanlı Devleti'nde mühürler, diplomatik bir unsur olarak incelenmektedir. Devletin ilk dönemlerinden itibaren resmi evrakta kullanılan mühür, evrak sahteciliğinde taklit edilen veya sahtesi imal edilen bir meta olarak kullanılmıştır. Bu çerçeve içerisinde mühür kazıma sanatı olan hakkâklık mesleği ile tatbik defterleri konumuzla ilintili olarak ele alınmıştır. Hakkâklık mesleğinin tarihi seyrinin yanı sıra 19. yüzyıldaki problemleri sahte mühür kullanımı açısından, Osmanl devlet dairelerinde tutulan mühür tatbik defterleri ise muhteva yönünden incelenmiştir. Ayrıca özellikle 19. yüzylldaki hadiselerden örnekler verilerek evrak ve mühürde sahtecilik olayları irdelenmiştir. Osmanlı Devleti'nin sahtecilik olaylarına karşs uyguladığı cezai müeyyidelere de yer verilen çalışmamızda Tanzimat döneminin önemli devlet adamlarından Mehmet Emin Ali ve Mehmet Ali Paşaların isimlerinin karıştığı iki ayrı mühür davası değerlendirilmiştir.
\end{abstract}

Volume 9

Issue 4

November 2017

\begin{abstract}
Anahtar Kelimeler: Diplomatik, Mühür, Sahtecilik
Abstract: In this work, seals in Ottoman Empire are studied as a diplomatic element. Seal, used in official documents from the earliest times of the empire, was used as a meta in forgery of documents by making imitations or producing counterfeits. Within this framework, profession of Hakkak, which is the art of engraving seals, and application books were studied in relation to the subject. Along with the historical process of the profession of Hakkak, its problems in 19th century were studied in terms of fake seal usage. Besides, application books kept in Ottoman Empire were analysed with regard to their contents. In addition, examples of forgery in documents and seals especially taken from incidents in 19th century were studied. In our study, which includes penal santions that the Ottoman Empire practised against forgery, two different cases of fake seal involving two prominent statesmen of Tanzimat Reform Era, Mehmet Emin Ali and Mehmet Ali Pasa were examined.
\end{abstract}

Keywords: Diplomatics, Seal, Forgery

\section{Giriş}

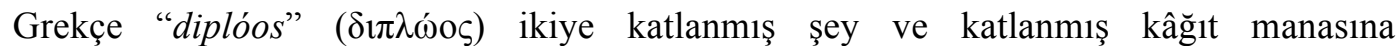
gelen "diploma" $(\delta i ́ \pi \lambda \omega \mu \alpha)$ kelimelerinden türetilmiş olan diplomatik, kavram ve bilim dalı olarak 17. yüzyıl Avrupa'sında ortaya çıkmıştır. ${ }^{1}$ Ortaçağ Avrupa'sında resmi evraklar için kullanılmayan diplomatik, daha sonraki dönemlerde Fransızca'ya girmesiyle birlikte şahadetname, berat ve imtiyaz manalarında kullanılmaya başlanmıştır. Bu kullanımı ile birlikte diplomatik, resmi belgeleri içerik ve şekil yönünden inceleyen bir ilim dalı olarak kabul edilmiştir. ${ }^{2}$ Resmi muhtevası olan yazışmaların sistematik bir nesne olarak değerlendirilmesini sağlayan diplomatik ilminin ortaya çıkış gerekçesi ise Avrupa'da bir evrakta sahtecilik

\footnotetext{
${ }^{1}$ Mübahat S. Kütükoğlu, Osmanlı Belgelerinin Dili (Diplomatik), TTK Yayınları, 3. Baskı, Ankara 2013, s.3.

${ }^{2}$ Kütükoğlu, age, s.3.
} 
hadisesinin yaşanmasıdır. ${ }^{3}$ XVII. yüzyıl sonlarında meydana gelen bu hadisenin sonucunda yazışmalarda dikkat edilecek hususlar ile resmi yazının şekil ve muhteva yönünden incelenmesi ilk kez gündeme gelmiştir. Şöyle ki Milano'lu piskoposluk üyelerinin gerçekliğini araştırmak üzere Papalığa gönderdikleri 1198-1216 yıllarında Papalık yapmış olan İnnocent'e ait bir mektubun sahte olduğunun tespit edilmesi üzerine Papalık, gerçek belge ile sahtesi arasındaki farkları ortaya çıkarmak için birtakım çalışmalar başlatmıştır. ${ }^{4} \mathrm{Bu}$ hadise, Diplomatiğin ontolojik sürecinin bir ilim dalı olarak günümüze kadar gelmesinde milat olarak değerlendirilmektedir. Diplomatik, Osmanlı Devleti'nde bir disiplin kaygısının güdülmeden belgelerin neşredildiği Münşeat Mecmuaları'nda ilk defa ortaya çıkmıştır. Bir kısmında diplomatik kaidelere de yer verilen bu mecmualar, Osmanlı'da diplomatiğin temellerini oluşturmaktadır. Nihayet 1909 yılında Tarih-i Osmânî Mecmuası'nın kurulması ile diplomatiğe bir disiplin nazarı ile bakılmış ve bu alanda birtakım ilmi çalışmalar yapılmıştır. ${ }^{5}$ Diplomatiğin Avrupa'da disiplin olarak ortaya çıkışındaki gerekçe yani sahte evrak tanzimi, Osmanlı Devleti'nde de söz konusu olmasına karşın Osmanlı Devleti resmiyet kazanan herhangi bir evrakı formal incelemelere tabi tutmamıştır. Evrak sahteciliği hususunda derli toplu bir girişimde bulunulmayan Osmanlı Devleti'nde sadece bazı bürokratik kademelerde bir takım önlemler alınmaya çalışılmıştır.

Diplomatiğin konusu olan belge sahteciliği, kavramsal olarak birçok sahtecilik olayını kapsamaktadır. Belgenin şekil ve muhteva açısından deforme edilmesi, belgenin sahte örneğinin çıkarılması ya da aslı olmadığı halde uydurma belgeler oluşturma gibi uygulamalar da belge sahteciliğine girmektedir. Nitekim XVI. yüzyılda Feridun Ahmet Bey'in Osman Gazi'ye ait olduğunu iddia ettiği bazı belgelere eserinde yer vermesi, evrakta sahtecilik olarak değerlendirilmiştir. ${ }^{6}$ İnsanlar, ister kamu hizmetinde ister sivil vatandaş olarak şahsi menfaatlerini gözetmek suretiyle sahte evrak tanzim etme yolunu tercih edebilirler. $\mathrm{Bu}$ bakımdan Feridun Ahmet Bey'in böyle bir yola tevessül etmesindeki gayesini de "çıkar sağlamak" şeklinde açıklamak mümkündür. ${ }^{7}$ Bu durum yukarıda da kısaca değinildiği üzere Hıristiyan dünyasında da bir problem olarak görülmüş ve bir takım tedbirlere başvurulmuştur. ${ }^{8}$

Osmanlı klasik döneminde sahte evrak tanzim etme işi daha çok ferman ve beratlarda görülmektedir. Bu tür evraklarda mühür olmadığı için ya Osmanlı bürolarındaki ferman ve berat kâğıtlarının ele geçirilmesi ya da bu büro personelinin sahte tuğra çekmesi suretiyle sahte evraklar tanzim edilmiştir. Bu bakımdan belgenin sahte olup olmadığ 1 hususu genellikle şekil özellikleri ve içeriğinden anlaşılmaktaydı. Zira Feridun Ahmet Bey'in neşrettiği belgelerin sahte olduğu, üzerinden uzun bir dönem geçtikten sonra sunulan belgelerin dil özelliklerinin dönemini yansıtmadığı saptanarak ortaya çıkarılmıştır. Ancak buradaki başlıca sorun, belgenin resmi devlet kurumları ya da yetkilileri tarafından işleme tabi tutulduğu esnada sahte olup olmadığının tespit edilebilmesidir. Çünkü belgenin tabi tutulduğu bürokratik işlemin sağlıklı

\footnotetext{
${ }^{3}$ Avrupa tarih yazımına göre diplomatik kavramını ilk kez kullanan ve uygulayan Benediktin Tarikatı üyelerinden Dom Jean Mabillon (1632-1707) adlı kişidir. Mabillon'un, Cizvitler Tarikatına karşı kendi tarikatını savunmak ve bunun Merovenj hanedanı zamanında yazılan Saint-Denis Bazilikasının gerçekliğini ortaya koymak için De re diplomatica (Paris 1681) adlı eseri kaleme almasıyla birlikte diplomatik bilimi ortaya çıkmıştır. Bkz. Mark Mersiowsky: "Ausweitung der Diskurszone um 1700. Der Angriff des Barthélémy Germon auf die Diplomatik Jean Mabillons", içinde Thomas Wallnig, Thomas Stockinger, Ines Peper, Patrick Fiska (Hg.), Europäische Geschichtskulturen um 1700. Gelehrsamkeit, Politik und Konfession. Berlin 2012, s. 447-484; 648-661.

${ }^{4}$ Kütükoğlu, age, s.4.

${ }^{5}$ Kütükoğlu, age, s.5.

${ }^{6}$ Mübahat Kütükoğlu, "Diplomatik”, Türkiye Diyanet Vakfi İslam Ansiklopedisi (DİA), C.9, 1994, s.364; Bilgin Aydın- İshak Keskin, "Osmanlı Bürokrasisinde Evrak Sahteciliği, Diplomatik ve Diplomatika Eğitimi”, Osmanlı Araştırmaları Dergisi, C.XXXI, İstanbul 2008, s.199-200.

${ }^{7}$ Aydın-Keskin, agm, s.199-200.

8 İlgili örnekler için bkz. Aydın-Keskin, agm, s.213-214.
} 
bir şekilde yürümesi ve neticelenmesi, Osmanlı bürolarında geliştirilen birtakım usullerden geçmesiyle mümkündü. Klasik dönemde Veziriazam, Eyaletlerdeki vezirler, Beylerbeyi ve Sancakbeyi gibi üst düzey devlet görevlilerinin imza hükmünü taşıyan pençe çekmesi ve evrakın gerçekliğini gösteren sahh adındaki simgenin kullanılması, Osmanlı diplomatikasında yazışma güvenliğinin sağlanmasına yönelik uygulamalardı. ${ }^{9}$ Bunun yanı sıra evrakın gerçekliğini göstermek maksadıyla mühür kullanılması da tercih edilen uygulamalardan biriydi. Şeyhülislâm Mirza Efendi'nin İlk kez, 1714 yılında, verdiği fetvaya mühür vurulması böyle bir kaygın ürünü olsa da verilen fetvanın taklit edilmesini ve mührün çalınarak basılması gibi durumları önlemek için fetvayı Şeyhülislam'ın kendi el yazısıyla yazmasına da ayrıca önem verilmişti. ${ }^{10}$

\section{Osmanlı Devleti’nde Diplomatik Bir Unsur Olarak Mühür}

Esasen bir belgenin gerçekliğinin belirtilmesi veya sahtelerinin türemesinin önlenmesi diplomatiğin bir disiplin olarak ortaya çıkmasından çok daha önceki dönemlerde gündemde olan bir mesele idi. Eski çağlardan itibaren resmi evraklarda mühür kullanılmasının temel nedeni evrakta sahteciliği önlemekti. ${ }^{11}$ Farsça bir kelime olan mühür, Sasaniler'in tesiri neticesinde İslam devletlerinde resmi bir mahiyet kazanmıştır. ${ }^{12}$ Yazışmalarında mühür kullanan Hz. Peygamberin bu uygulaması Emeviler ve Abbasiler dönemlerinde yaygınlaşarak devam etmiştir. ${ }^{13}$ Osmanlılar, diplomatik/bürokratik alanlardaki birçok kavram gibi Arapça hatem teriminin yerine Farslardan iktibas edilen ve Arapça kalıplar vasıtasıyla memhur (mühürlü), temhir (mühürlemek) gibi yeni kelimeler türeterek ${ }^{14}$ mührü diplomatik bir unsur haline getirmişlerdir. Osmanlı Devleti'nin ilk dönemlerinde başta Padişah olmak üzere devlet görevlilerinin ve sivil halkın mühür kullandığı bilinmektedir. Hatta hanedanın kadın üyeleri gibi halktan kadınlar da şahsi mühürlere sahiptiler. ${ }^{15} \mathrm{Bu}$ mühürler, mühür sahibinin statüsü ve mali durumuna göre altın, gümüş, akik, zümrüt gibi değerli taş ve madenlere ya da bakır gibi daha az değerli madenlere kazınmaktaydı.

Mühür; Padişah'ın nüfuz ve yetkilerinin temsil edilmesi bakımından tuğradan sonra en önemli nişane olarak kabul edilirdi. ${ }^{16}$ Tanzimat'tan önce sadece Yeniçeri A ğası, Defterdar, Topçubaşı ve Muhasebeci gibi devlet görevlilerinin yalnızca makam adı mühürlerde yer alırken; Tanzimat'la birlikte neredeyse bütün kurumlarda makam adı ve mühür sahibinin ismi birlikte kullanılmıştır. ${ }^{17}$ Kütükoğlu'na göre mühürleri genel manada üç kısma ayırmak mümkündür: bunlar sadece şahıs isimlerinin yer aldığı, yalnızca makam isimlerinin kazındığ ya da her ikisinin de yazılı olduğu mühürlerdir. ${ }^{18}$ Bunların yanı sıra şahıs ve makam

\footnotetext{
9 Yazının kime ait olduğunu göstermek açısından Osmanlı Devleti'nde en önemli işaret Padişah tuğrası ile mührüydü. Diğer devlet görevlilerinin kullandığ 1 pençe ve mühürler bunu takip etmektedir. Bkz. Kütükoğlu, Osmanlı Belgelerinin Dili, s.71; İ.Hakkı Uzunçarş1lı, "Tuğra ve Pençeler ile Ferman ve Buyuruldulara Dâir", Belleten, C.V/17-18, Ankara 1995, s.111-112 vd: Uzunçarşılı'nın bir kısım devlet ricalinin mühürlerini incelediği makalesi için ayrıca bkz. İ.Hakkı Uzunçarşı1ı, "Osmanlı Devleti Zamanında Kullanılmış Mühürler Hakkında Bir Tetkik", Belleten, C.IV/16, 1940, s.495-544.

${ }^{10}$ İsmail Hakkı Uzunçarşıll, Osmanlı Devletinin İlmiye Teşkilâtı, TTK Basımevi, 3. Baskı, Ankara 1988, s.204.

11 Farklı kullanım alanları olmasıyla birlikte tarihi kalkolitik dönemlere kadar uzanan mührün, bazı Osmanlı Padişahlarınınki de dahil olmak üzere İslam Devletlerinde kurşun mühür olarak kullanılan örnekleri için bkz. Halil Edhem, Müze-i Hümâŷ̂n Kurşun Mühür Kataloğu, Mahmud Bey Matbaası, Konstantiniyye 1321.

${ }^{12}$ Aydın-Keskin, agm, s.207.

${ }^{13}$ Bkz. Halil Edhem, age.

${ }^{14}$ M.Tayyib Gökbilgin, Osmanl Paleografya ve Diplomatik Illmi, Enderun Kitabevi, İstanbul 1992, s.49; Mübahat Kütükoğlu, "Mühür", Dİ, C.31, 2006, s.530.

${ }^{15}$ Kütükoğlu, agm, s.530; . Hammer, Osmanlı Mühürleri, (Çev: Ümit Öztürk), Pera Yayınları, İstanbul 1999,s.78.

${ }^{16}$ Gökbilgin, age, s. 50 .

${ }^{17}$ Kütükoğlu, "Mühür", s. 531.

${ }^{18}$ Kütükoğlu, age, s.87.
} 
isimlerinin kazınmadığı fakat üzerlerine çeşitli yazıların yer aldığı mühürler de kullanılmıştır. ${ }^{19}$ Mühür kullanmak XIX. yüzyılın ortalarına kadar keyfi bir uygulama olarak görülüyordu. Evraklara sahh çekmenin bürokratik hantallığa yol açması ve taklit edilebilmesi, bu alanda yeni bir düzenlemeyi zorunlu kılmıştır. Bunun üzerine 1862 'de eski usulden vazgeçilmiş ve evrakta resmi mühür kullanımı zorunlu hale getirilmiştir. Sadrazam Fuat Paşa dönemindeki bu düzenleme neticesinde ilk olarak Fuat Paşa'nın adı ve vazifesi yer alan bir mühür kazdırılmış ve resmi yazışmalarda kullanılmaya başlanmıştır. ${ }^{20}$ Böylece Osmanlı devlet adamlarının şahsi mühürlerini (sadece ismin kazındığı mühürler) resmi evrakta kullanma teamülü genel olarak değişmeye başlamıştır. Osmanlı bürolarında ve makamlarında bu uygulamanın yaygınlaşmasıyla beraber mührün Osmanlı diplomatikasındaki yeri ve önemi artmıştır. Devletin son yüzyılındaki bu gibi bürokratik ve diplomatik düzenlemeler, aynı zamanda mühür kullanımında birtakım değişiklikleri beraberinde getirmiştir. Önceleri hiçbir izne tabi tutulmayan ve kişinin salahiyetine bırakılan mühür kazdırma uygulaması, bazı devlet görevlileri için geçerliliğini yitirmiştir. Örneğin yeni ihdas edilen Muhtarlık teşkilatında kullanılan mühürler, Darphane'de kazdırılarak ilgili muhtara gönderilmeye başlanmıştır. ${ }^{21}$

\section{Mühürcülük Sanatı ve Hakkâkların XIX. Yüzyıl Başlarına Kadarki Vaziyeti}

Osmanlı Devleti'nde mühür yapan kişilere hakkâk ${ }^{22}$ denirdi ve bunlar genellikle Kapalıçarşı'da bulunurdu. ${ }^{23}$ Osmanlı esnaf teşkilatında yerini alan bu meslek erbabı, ilkin saraya hizmet eden bir hüviyete sahipti. Saray için hazırlanan kuyumculuk eserlerine değerli taşları yontma ve yerleştirmeden sorumlu olan ve atölyeleri Darphane-i Amire'nin içinde bulunan bu hakkâklara, zamanla mühür kazıma işi de devredildi. ${ }^{24}$ Önceleri madenleri işleyen hakkâk esnafını Evliya Çelebi, "dükkânlarında akîk ve seylân ve yemeni ve pîrûze ve yeşim taşların hak ederek ubûr ederler" diye tavsif etmiş, mühür kazımaları hakkında herhangi bir bilgi vermemiştir. "Esnaf-1 mühür-kenân" olarak tanıttığı ve 5 dükkân ile 80 kişiden müteşekkil bir sınıfın vezirlere mühürler kazıdığını bildiren Evliya Çelebi, bunların yanı sıra 40 kişiden oluşan ve 15 dükkâna sahip bir başka esnaf sınıfının da gümüşten mühürler yaptıklarını ifade etmiştir. ${ }^{25}$ Esnaf içinden bir ustanın işlediği madenin cinsinin o sınıfın adına verildiği, ahkâm defterlerinde (örneğin 1759 yılı defterinde) yer alan "bakırcı hakkâkı"26 gibi tanımlamalardan anlaşılmaktadır. İlerleyen dönemlerde hakkâk denince mühür kazıma işi ön plana çıkmaya başlamışır ki bu durum, işleme sanatının gerilemesine mukabil mühür kullanımının yaygınlaşması olarak düşünülebilir. Osmanlı döneminde mühürler altın, gümüş, bakır, pirinç, kurşun ve başka değerli taşlara kazınırdı. İnce bir işçilik isteyen bu zanaat, mühürde yer alacak yazıyı tersten kazıyacak kadar iyi hattatlık becerisi gerektiriyordu. Dolayısıyla işleme sanatında maharetli olan bir usta hat sanatında da aynı derecede uzmanlaşmamışsa mühür kazıyamazdı. Hakkâkların mühür kazıma mesleğini elinde bulundurmasına rağmen kendileriyle benzer işler yapan diğer meslek dallarıyla bu konuda

\footnotetext{
${ }^{19}$ Bazı örnekler için bkz. Hammer, age, s.81-87.

${ }^{20}$ Ali Akyıldız, Osmanlı Bürokrasisi ve Modernleşme, İletişim Yayınları, İstanbul 2009, s.112-113; Kütükoğlu, age, s.89-90.

${ }^{21}$ Akyıldiz, age, s.76.

${ }^{22}$ Hakkâk kelimesi, kazımak, oymak anlamında Arapça hâk fiilinden türetilmiştir. Bkz. Mehmet Zeki Pakalın, Tarih Deyimleri ve Terimleri Sözlüğü, C.I, Milli Eğitim Basımevi, İstanbul 1971, s.706.

${ }^{23}$ BOA (Başbakanlık Osmanlı Arșivi), Meclis-i Vâlâ Evrâkı (BOA. MVL.), 459/79.

${ }^{24}$ Pelin (Filiz) Bozcu, Osmanlı Sarayında Sanatçı ve Zanaatçi Teşkilatı Ehl-i Hiref, (T.C. Kültür Bakanlığı Kültür Varlıkları ve Müzeler Genel Müdürlüğü Yayımlanmamış Uzmanlık Tezi), İstanbul 2010, s.34.

${ }^{25}$ Evliya Çelebi Seyahatnâmesi C.1, 1. Kitap, Hz.: Robert Dankoff, Seyit Ali Kahraman, Yücel Dağlı, Yapı Kredi Yayınları, İstanbul 2011, s.312.

26 İstanbul Esnaf Tarihi, C.I, Haz.: Ahmet Tabakoğlu, Ahmet Kal'a, Salih Aynural, İsmail Kara, İstanbul 1997, s.240.
} 
ihtilafa düştükleri vakidir. Zira mesleğin hattatlık gibi diğer inceliklerini öğrenen ustalar, mühür kullanımının yaygınlaşması ile birlikte mühür imal etmeye çalışmıştır. Örneğin Zernişancılar olarak bilinen ve altın gibi değerli madenleri kakma işiyle iştigal olan ${ }^{27}$ esnafın da mühür kazıma işine meyilli olması her iki meslek dalı arasında probleme neden olmuş, konu Padişah'a kadar ulaşmıştı. ${ }^{28}$ Tarihsel süreç içerisinde sayısında değişkenlik gözlemlenen hakkâk esnafi 16. yüzyılda 28 usta ve 27 şakirdan ile o zamana kadarki en kalabalık dönemini yakalamıştır. ${ }^{29} \mathrm{Bu}$ gelişimde Sultan I. Selim'in doğu seferleri etkili olmuştur; içlerinde çok sayıda hakkâkın yer aldığı zanaatkârlar Tebriz ve çevresinden İstanbul'a gelmiştir. ${ }^{30} \mathrm{Bu}$ gelişmelerin ardından 1600'lü yıllarda en iyi dönemini yaşayan mühürcülük sanatı, narh konulan dallardan biri haline gelmiştir. ${ }^{31}$ Fakat bu durum 1700'lü yıllarda değişmiş, esnaf sayısında hayli bir düşüş yaşanmıştır. Dönemin maaş defterine yansıdığı kadarıyla saraya bağlı olarak çalışan 3 hakkâk bulunmaktaydı. ${ }^{32} 19$. yüzyılın başlarında ise hakkâk sayısında yeniden bir artış olduğu görülmektedir ki 1810'lu yıllarda 20'nin üzerinde ruhsatlı ve kefilli hakkâk bulunmaktaydı. ${ }^{33}$ Hakkâk sayısının durumu ilerleyen yıllarda çok bir değişiklik geçirmemiştir, öyle ki 1873 yılında resmi olarak hizmet veren 15 hakkâk mevcuttu. ${ }^{34}$

Mühür kazıma işinin hangi esnaf sınıfının salahiyetinde olacağı meselesi, 19. yüzyılın başlarında dahi bir sorun oluşturmaktaydı. Nitekim bu dönemde hakkâk esnafının sanat dalları arasında yer alan bu işle diğer esnaf birimlerinin de meşgul olmaya başlaması neticesinde taraflar mahkemelik olmuştur. Şöyle ki hakkâk esnafı, bir kethüda, bir yiğitbaşı, bir de hakkâkbaşı ya da serhakkâk ile ustalardan oluşan bir sınıftan müteşekkildi. Sonradan bu teşkilata taş ve değerli madenleri alıp şekle sokan ve üzerine altın işleme yapan 20 Ermeni ustadan oluşan bir zernişancı sınıfı dâhil edilmişti. Bu birimin hakkâklara dâhil edilmesinin başlıca nedeni ise hakkâkların mühür kazıyacağı madenin ön hazırlık sürecinin bu birim tarafından tamamlanmasıydı. Ancak 21 kişiden oluşan ve çubuk imamesi işleyip etek üzerine altın işleme yapan Ermeni ustalar ile değerli taşları ve madenleri delip işleme işi yapan endamcı 26 kişiden oluşan Yahudi zanaatkârlar da iş alanlarını genişletmek, hakkâkların yaptığı işleri yapıp onların tezgâhlarına sahip olmak için başvuruda bulunmuşturlar. Ermeni ve Yahudi ustaların bu hakkı 26 Ocak 1813 (23 Muharrem 1228) tarihinde çıkan bir ferman ile elde etmeleri, hakkâk esnafını haliyle rahatsız etmiştir. Çünkü kendileriyle aynı haklara sahip olan bu Ermeni ve Yahudi ustalar nedeniyle hem gelirlerini düşüreceğinden hem de bu tezgâhlarda sahte mühür kazınacağından endişe duymaktaydılar. Bu sebeple Hakkâk esnafı, ancak kefil gösterilerek hakkâklığa dâhil olunabilen bu yeni ustalara kefil dahi olmamışlardır.

${ }^{27}$ Bozcu, age, s.36.

${ }^{28}$ BOA, Cevdet İktisad (BOA. C. IKTS.), 25/1227, 15 May1s 1818 (1233.B.9).

${ }^{29}$ Bozcu, age, s.35.

${ }^{30}$ BOA, Topkapı Sarayı Müzesi Arşivi (TS.MA.): Defter (d.) 9784; İran’da hakkâklık ileri seviyede bir sanat dalıydı. Osmanlı mühürlerinin Fars mühürlerine nazaran büyüklük, çeşitlilik ve işçilik bakımından daha gelişmiş olduğuna işaret eden Hammer, özellikle İsfahan bölgesinde İstanbul'dakilerden daha kaliteli hakkâklar olduğunu ifade etmektedir. Bkz. Hammer, age, s.21-22.

31 İbrahim Kemal Baybura, "Osmanlılarda Mühür”, Topkapı Saray Müzesi Yıllık II, İstanbul 1987, s.70.

${ }^{32}$ Bozcu, age, s.35.

${ }^{33}$ Hakkâk sınıfı şu kişilerden oluşmaktaydı: Hakkâk Kethüdası: Abdullah, Serhakkâk: Ahmed Rahmi, vekili sıfatıyla Mustafa İzzet, Hakkâk Yiğitbaşısı Mustafa efendiler ile ustalardan; Mehmed Emin, Şakir efendi ile çırağı İbrahim Edhem, Hafiz Ahmed Reşid, Osman, Hafiz Ahmed, Ahmed, Mehmed Halife, Salih Kamin?, Mehmed Tahir, Numan, Salih, Mehmed Salih, Mehmed Şakir, Mehmed Arif ile kardeşi Abdülkadir, Mehmed, Ahmed, Mehmed Şakir İzzi, Zaim Mehmed Emin, Hafız Mehmed, Mehmed Esat, Mustafa, Mehmed Feti. BOA, C.IKTS, 25/1227.

${ }^{34}$ BOA, Şûrâ-yı Devlet (ŞD), 2864/13. İsimleri şöyledir: Ali Rıza, Mehmed Said, Hüseyin, Mehmed Şakir, Mehmed Sırrı, Hüseyin Hüsnü, Azmi, Abdülhalim, İsmet, Hafız Resmi, Abdülkadir, ?, Mehmed Nazif, Aziz Mahmud ve Sami; Bazı ün yapmış hakkalar için bkz. Mithat Sertoğlu, "Kaybolan Bir Türk Sanatı Mühürcülük", Resimli Tarih Mecmuasl, C.VII/12, İstanbul 1956, s.741-745. 
Bunun haricinde Hakkâk esnafı karşı bir hamle yaparak 30 Mart 1813 (27 Rebiülevvel 1228) tarihinde mühür kazıma işinin sadece kendilerine ait olduğuna ve bunun dışındaki ustaların mühür kazıma ve mühür alım satım gibi işlerde sınırlı yetkilere sahip olduğuna dair bir fermanın yayınlanmasını sağlamışlardır. Ancak Ermeni ve Yahudi esnafın bu fermanın hükümlerine göre hareket etmedikleri için hakkâk esnafı, kethüdaları Abdullah Efendi öncülüğünde bir arzuhal kaleme aldılar. Kendi teşkilatlarına bağlı olarak çalışan 20 kişilik Ermeni ustaların kefil usulüne bağlı olarak çalışıp nizama mugayir bir hareketi olmadığını, bunların teşkilat için yeterli sayıda olduğunu bildiren hakkâk esnafi, diğer 47 kişiden oluşan Ermeni ve Yahudi ustaların aldığ fermanın bozulmasını ve teşkilattan çıkarılıp ruhsat verilmemesini talep ettiler. Ayrıca konuyu mahkemeye taşımak niyetinde oluklarını ve uygun görülür ise Arz Odası'nda şer'i duruşma yapılmasını talep ettiler. Bu talebin hükümet tarafından kabul edilmesi üzerine hakkâklar, zernişancılar ve diğer Ermeni ile Yahudi ustalar Arz Odası'nda bir araya getirilerek mahkeme edildi. Uzun süren duruşma neticesinde Hakkâk esnafının talepleri ve kaygıları haklı bulunarak diğer ustalar, ellerindeki ferman ilga edilmek suretiyle yalnızca kendi mesleklerini icra etmelerine ruhsat verilerek mühürcülük sanatından men edildi. Bir başka oturumda ise İstanbul'daki bütün taş, maden, kalay, tombak gibi eşyaların yontulması ve işlenmesinde mahir olan ustalar ile kuyumcular toplanarak şu önemli kararları almışlardır:

a) Hakkâk esnafı dışında kimse tarafından mühür kazınmaması,

b) Üzeri yazılı taş ve mühürlerin gizlice alınıp satılmaması,

c) Alenen satın alınan mühür ve üzeri yazılı sınırlı sayıdaki taşların derhal hakkâk esnafina satılması.

Bu kararlara uyulacağına dâir bütün ustalar birbirine kefil tutulmuş ve hepsine yemin ettirilmiştir. Yukarıdaki kararları uygulamayanların, Hakkâklar Kethüdası'na ve Bâbıâli'ye bildirilmesine dâir 29 Haziran 1813 (29 Cemaziyelahir 1228) tarihli bir başka karar, İstanbul Kadısı'nın Mayıs 1818 (Recep 1233)'deki ilamıyla noktalanmıştır. ${ }^{35}$

$\mathrm{Bu}$ gelişmeler ile Tanzimat dönemine yaklaşırken Osmanlı diplomatikası ve bürokrasisinde önemli bir unsur olmaya başlayan mühürleri kimlerin hangi şartlarda imal edeceği meselesi büyük bir oranda çözüme kavuşturuldu. Ancak aşağıda görülecektir ki resmi evraklarda sahtecilik yapanların haliyle sahte bir mühür kullanması icap edeceğinden bu mesele gündemi yeniden meşgul etmeye başlayacaktır. Bu gibi teknik meselelerinin yanı sıra Osmanlı bürokrasisinde gittikçe yaygınlaşan mühür kullanımı hususunda herhangi bir sahtekârlığa mahal vermemek için birtakım uygulamalar yapıldı. Bunların belki de en önemlisi aşağıda ele alınacağı üzere, evraktaki mührün karşılaştırılmasını sağlayan defterlerin tanzim edilmesiydi.

\section{Resmi Muamelelerde Tedbirî Bir Uygulama Olarak Mühür Tatbik Defterleri}

Osmanlı bürokrasisi içinde göreve yeni başlayan kişiler, hâlihazırda kullandıkları ya da yeni yaptırdıkları mühürlerin bir kopyasını Dersaadet'e göndermek zorundaydılar. Evrakta sahteciliği önlemek için klasik dönemden itibaren kullanılan mühürlerin örnekleri tatbik mührü adıyla merkeze gönderilir ve ilgili dairede muhafaza edilirdi. Bunlar için genellikle tatbik mühür defterleri adında hususi defterler tanzim edilirdi ya da bazı durumlarda ilgili mevkiin harcamalarının tutulduğu defterlere mühür örneği yapıştırılırdı. ${ }^{36}$ Tatbik defterlerine basılan mührün üst ya da yan tarafinda mührün kime ait olduğu yer alırdı veya bu husus bazı

${ }^{35}$ BOA, C.IKTS, 25/1227.

${ }^{36}$ Kütükoğlu, "Mühür", s.530. 
defterlerde mühürde yazan yazı ile birlikte dercedilirdi. ${ }^{37}$ Klasik dönem Osmanlı bürokrasisinde mühür kullanılan belgelerin tatbik edildiği görülmektedir. $\mathrm{Bu}$ bakımdan merkeze ulaşan bir belgede bakılan ilk unsurlardan biri de belgenin mührü idi. Bürokratik muameleler başlamadan önce belgeye tatbik yazısı eklenir ve defterlerden mührünün gerçekliği araştırılırdı. Mühür sahih ise ișleme devam edilirdi. Belge sahte mühürlü ise yanına sahtedir yazılarak düzenleyen kişi hakkında hukuki işlem başlatılırdı. ${ }^{38}$ Sonraki dönemlere nazaran mühür kullanımının az olması nedeniyle yürürlükte olan bu uygulama, ekseriyetle akçeli işlerde kullanılırdı. Tımar arzları üzerinden belgelerin muamelatı hakkında önemli tespitlerde bulunan Halil İnalcık, arzlarda kullanılan mühürlerin tatbiklerinin yapıldığına ve belgenin gerçekliğinin bu işlemi yapan memurun sahihtir ibaresi ile tasdik edildiğine dikkat çekmiştir. ${ }^{39} \mathrm{Bu}$ işlemin yanı sıra ilgili mührün yanına mutabıkdır yazılmak suretiyle de mührün tatbik edildiği görülmektedir. ${ }^{40}$ Eflak-Boğdan ve Kırım gibi özel statüye sahip olan toprakların Beyleri yahut Girayları dahi tatbik mührü uygulamasına tabi tutulmuştur. ${ }^{41} 19$. yüzyılda Osmanlı yazışmalarında mühür kullanımı hayli arttığından bazı birimlerde tatbik işini görmek üzere hususi memurlar istihdam edilmiştir. Mesela hicri 1217 yılında (m. 1802-1803) ihdas edilen Sehm Ruznâmesi Kalemi'ndeki tatbikcinin görevlerinden biri de tahvil sahibinin mührünü eshâm tahvillerindeki kayıtlardan istifade ederek tatbik etmekti. ${ }^{42}$ Bununla birlikte Topkapı Sarayı Müze Arșivi'nde Hakkâkların da kazıdığı mühürleri kaydettikleri defterlere ulaşılmıştır. ${ }^{43}$ Böylece herhangi bir sahtekârlık durumunda hakkâk defterleri de başvuru kaynağı olarak olayın aydınlatılmasında kullanılabiliyordu. Fakat bu salahiyetin hangi hakkâklara verildiği hususu kesinlik arz etmemektedir.

HISTORY STUDIES

189

Volume 9

Issue 4

November 2017

Farklı sebeplerden dolayı hükmünü yitiren mühürler, muhakkak defterlerde gösterilirdi. Böylece defterlerden istifade ederken işlem kargaşalığı engellenerek defterlerin güncelliğinin korunması sağlanırdı. Hükmünü yitiren mühürlerin üzeri çizilir ya da üzerine bazı açıklamalar yapılırdı. Tarafımızca yapılan incelemede hükmünü yitiren mühürlerin üzerinde üç tip açıklama tespit edilmiştir. Bunlar;

1- Kayıp ya da benzer bir nedenden ötürü mühür kullanılamaz hale gelmiş ise zayi, ${ }^{44}$

\footnotetext{
${ }^{37}$ Örnek bir mühür tatbik defterine bkz. Ek 1.

${ }^{38}$ Kütükoğlu, age, s.96; Örnek bir belgeye bkz. Ek 2.

${ }^{39}$ Halil İnalcık, "Osmanlı Bürokrasisinde Aklâm ve Muâmelât", Osmanlı Araştırmaları I, İstanbul 1980, s.4.

${ }^{40}$ Örnek belgelere bkz. İnalcık, agm, s.9; Kütükoğlu, age, s.567,594.

${ }^{41}$ Mehmed Giray ve Mübarek Giray'ın Tatbik mühürlerine bkz. Ek 4.

42 Ali Akyıldız, Tanzimat Dönemi Osmanlı Merkez Teşkilâtında Reform (1836-1856), Eren Yayınları, İstanbul 1993, s.102.

${ }^{43}$ Baybura, agm, s.73; Kütükoğlu, age, s.97.

44 Vakıf mühür tatbik defterleri üzerine bir araştırma yapan Sadi Bayram'ın neşrettiği mühürlerde zayi olan mühürler ile ilgili yeniden mühür kazdırılmışsa “.... efendi mührünü zayi etmekle işbu mühür hıfzolunmuşdur” şeklinde, eğer defterdeki mühür zayi olmuşsa "işbu mühür zayi olmağla müceddeten mühür vaz olunmuştur. Amel olunmaya" şeklinde bir açıklama yapıldığı görülmektedir. Bkz. Sadi Bayram, "Vakıflar Genel Müdürlüğü Arşivinde Bulunan 1783-1810 Yılları Arasında İşlem Görmüş Bir Mühür Tatbik Defteri", III.Uluslararası Türk Kültürü Kongresi Bildirileri Ankara 25-29 Eylül 1993, Hz.: Alev Kahya Birgül, Atatürk Kültür Dil ve Tarih Yüksek Kurumu, Ankara 1999, s.310-311.
} 


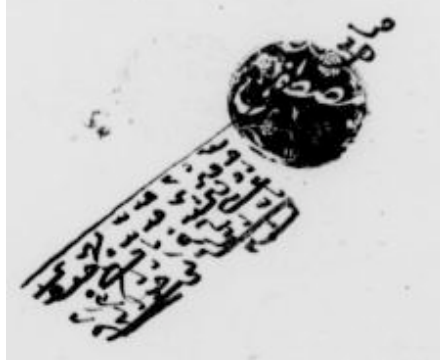

Zayi olmuş bir mühür (BOA, D.M. MÜHRd, 37330/4)

2- Görevini bırakanlar için el çekme, feragat etme manasında kasr-l yed,

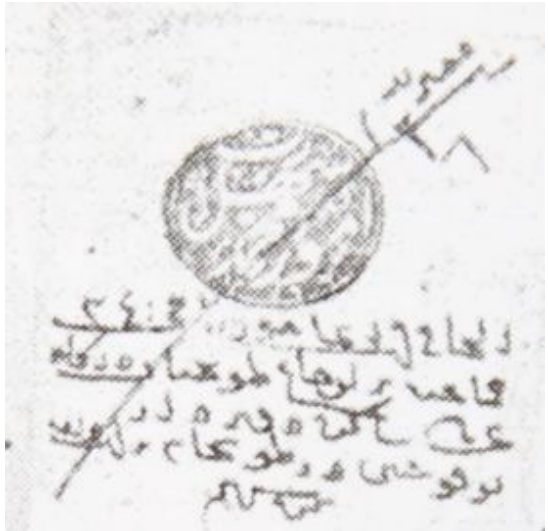

Kasır-1 yed şerhli mühür (Kütükoğlu, Osmanlı Belgelerinin Dili, s.429)

3- Mühür sahibi vefat etmiş ise müteveffâ ya da kısaca mim harfi yazılırdı.

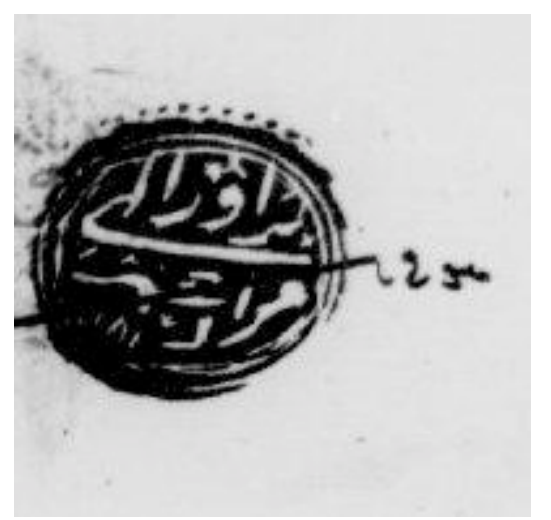

Müteveffâ şerhli mühür (BOA, D.M. MÜHRd, 37330/4)

Yukarıdaki uygulamaların dişında Mustafa Reşid Paşa zamanında daha köklü çözüm arayışına gidilmiştir. Bu bağlamda isim ve mahlas karışıklı̆ını önlemek için mühürlerin yanına mührün sahibi tarafindan ayrıca imza atma uygulaması ilk defa bu dönemde ortaya çıkmıştır. Bu şekilde bürokratik yazışmalardaki hantallığın giderilmesi hedeflenmekteydi. ${ }^{45}$ Tanzimat'ın ilanından sonra lağvedilen bazı memuriyetlerde tatbik mührü uygulaması

${ }^{45}$ BOA, Yıldız Esas Evrakı (Y.EE), 78/141, Akyıldız, Osmanlı Bürokrasisi ve Modernleşme, s.111. 
hükmünü yitirdiği gibi ihdas edilen kurumların personelleri için de bu uygulama aynen devam etmiştir. Mesela Tanzimat'tan sonra kurulan merkez ve taşra meclislerindeki bütün üyelerin tatbik mührünü göndermesi şarttı. Eyalet ve Liva meclislerinin üyelerinin tatbik mühürleri Bâbıâlî’ye gönderilerek buradan Hazine'ye aktarılırdı. 21 Aralık 1860 (7 Cemaziyelahir 1277) tarihli Sadaret emrinden itibaren bu mühürler doğrudan Hazine'ye gönderilmeye başland.. ${ }^{46}$ Bunun yanı sıra Bâbıâli yönetimi bazı zamanlarda çıkardı̆̆ı emirnamelerde görevlilerin mühür örneklerini göndermelerini talep etmekteydi. İstanbul dışındaki meclislere üye tayin edilenlerin tatbik mührü şu muameleye göre gönderilirdi: Kişinin üye olduğu meclisin bağlı bulunduğu vilayetin Valisi ilgili kişinin tatbik mührü ekte olmak suretiyle Dersaadet'e bir tahrirat gönderir, bu tahrirat ve eki incelenmek üzere Meclis-i Vâlâ'ya havale edilir, buradan da Maliye Nezareti'ne gönderilerek hazine tarafından gerekli mali işlemlerin yapılması talep edilirdi. ${ }^{47}$

Klasik dönemde Osmanlı merkez bürolarına gelen mühürlü evrakla ilgili ilk işlemin, mührünün tatbik edilmesi olduğuna daha önce değinilmişti. Ancak özellikle Tanzimat'la birlikte başlayan yeniden yapılanma sürecinde Bâbıâli bürolarının gelen evraka böyle bir muamele hükmü yer almamaktadır. 1861 yılında çıkarılan Bâbıâi Evrak Odası Nizamnamesi'nde ${ }^{48}$ her ne kadar İstanbul'daki devlet dairelerinden Sadaret'e gelen evraklar bu odada işlem görseler de kurumsal yahut şahsi mühürlerin tatbik edilmesine dair bir maddeye yer verilmemiştir. Dolayısıyla klasik döneme nazaran Osmanlı Devleti'nin son dönemlerinde mühür tatbikinin sistemli bir şekilde yapılmadığı düşüncesi ağırlık kazanmaktadır.

Buraya kadar mührün Osmanlı yazışmalarındaki kullanımı hakkında bilgiler verildi ve evrak sahteciliğini önlemek için alınan tedbirlerden bahsedildi. Aşağıda ise bu tedbirlere rağmen yazışmalarda sahte mühür kullandığı tespit edilenlere yapılan cezai işlemler üzerinde durulacaktır.

\section{XIX. Yüzyılda Mühürde Sahtecilik Olayları}

Sahte mühür kullanımı, diplomatikanın ortaya çıkışında ana unsur olarak kabul edilen sahte evrak tanziminin bir parçası olarak değerlendirilebilir. Bunun haricinde sahte evrak tanzimi için muhakkak mühür kullanmaya gerek kalmayan durumlar da söz konusudur. Mesela ferman ve beratlar gibi mühürsüz evraklarda sahtecilik yapmak için sahte mühür kullanmaya gerek yoktur. Ayrıca sahte evrak, evrak üzerinde formal değişiklikleri de içine alan bir tanımlamadır. Bu bakımdan sahte belge düzenleme işi daha önce de değinildiği üzere Osmanlı Devleti'nin ilk dönemlerinden itibaren vardı. Bu sahteciliğe verilen cezalar ise belli bir kanuna binaen değil, teamülen verilmekteydi. Evrakın önem derecesine ve suç ortaklarının pozisyonlarına göre cezalar değişmekteydi. Bunlar, suçu işleyenlerin idam edilmesi ve elinin kesilmesi gibi en ağır cezaları ya da bunlara görevden el çektirme gibi basit cezaları kapsamaktaydı. ${ }^{49}$ Ayrıca 16. yüzyılda sahte belge düzenlemenin küreğe konmayla da ${ }^{50}$ cezalandırıldığı bilinmektedir. Sultan II. Mahmud'un 7 Ekim 1820 (29 Zilhicce 1235) tarihli bir hatt-1 hümayununda bu konuyla ilgili bir olaya şahit olunmaktadır. ${ }^{51}$ Fındıklı semtinde

${ }^{46}$ BOA, Sadâret Mektûbî Kalemi Umûm Vilâyât Evrâkı (A.MKT.UM.), 446/54.

${ }^{47}$ Bir belgedeki muamelat için bkz. BOA, Sadâret Mektûbî Kalemi Nezâret ve Devâir Evrâkı (A.MKT.NZD.), 91/99, 27 Eylül 1853 (1269.Z.23).

${ }^{48}$ Murat Candemir, Bâb-ı Âli Evrâk Odası, (İstanbul Üniversitesi Sosyal Bilimler Enstitüsü Tarih Anabilim Dalı Yayımlanmamış Doktora Tezi), İstanbul 2002, s.61 vd.

${ }^{49}$ Kütükoğlu, age, s.123.

${ }^{50}$ Mehmet İpşirli, “XVI. Asrın İkinci Yarısında Kürek Cezası İle İlgili Hükümler”, İstanbul Üniversitesi Edebiyat Fakültesi Tarih Enstitüsü Dergisi, S:12, 1981-1982, s.211.

${ }^{51}$ BOA, Hatt-ı Hümâyûn (HAT), 1313/51167. 
ikamet eden Hacı Sadullah isimli birinin sahte mühür ile devlet görevlilerine mektup yazdı̆̆ 1 tespit edilmişti. Karahisar Mutasarrıfı'na yazdığı sahte mühürlü bir mektubun ortaya çıkması üzerine Sultan II. Mahmud, idam cezası verilen Sadullah Efendi'yi Magosa Kalesi'ne kalebentliğe mahkûm etmeyi yeğlemişti. Bu tür olaylar oldukça Arzuhalci Kethüdaları dâhil olmak üzere Hakkâklar ve ilgili esnaf kethüdaları şiddetli bir şekilde uyarılıyordu. Bununla beraber Hakkâklık sanatının itibarını zedelediği gerekçesiyle sahte mühür kazıyana, mührü kazdırandan daha ağır cezalar verilirdi. Örneğin bu gibi suçlarda hakkâklara 6 ay, olayın failine ise 4 ay pranga cezası gibi cezalar verilmekteydi. ${ }^{52}$ Bunun yanı sıra sahtekârlık olayına karışan hakkâklar, sanatı elinden alınarak, hakkâklık mesleğinden men edilirdi.

Tanzimat döneminde sahte mühür kullanımı genellikle borç senetlerinde, ${ }^{53}$ mürur tezkerelerinde, ${ }^{54}$ fetvalarda ${ }^{55}$ kadılık tezkirelerinde ${ }^{56}$ ve tahvillerde görülmekteydi. Tahvilde sahteciliğe lağımcı esnafindan Kayserili Derviş adında bir kişinin Lağımcıbaşı İsmail adına Beşiktaş'ta mühür yaptırarak sarraflardan tahvil almaya çalışmass ${ }^{57}$ örnek verilebilir. Şahsi çıkar sağlamaya yönelik bu gibi sahtecilikler, ilmiye teşkilatı da dâhil olmak üzere birçok alana yayılmıştı. Bazı naibler düzenledikleri uydurma tezkirelere vurdukları sahte mühürler ile kadılık mansıbı dahi vermekteydiler. ${ }^{58}$ Hatta merkez bürolarındaki memurların da sahte mühür ve evrak tanzim etmeye yeltendi $\mathrm{g}^{59}$ vakidir.

19. yüzyılın başlarında mühür kazıma salahiyetinin uzun süren muhakemeler neticesinde hakkâklara verilmesi hususu yukarıda ele alındı. Diğer esnaf birimleri gibi babadan oğula geçerek sürdürülen ${ }^{60}$ bu mesleğin uhdesindeki mühürcülük sanat1, Zernişancılar ve diğer esnaf teşkilatlarına yasaklanmasına rağmen, 1850 'lerde yeniden problemli bir hal almaya başladı. Ruhsatlı ve kefilli esnaftan olmayıp da İstanbul dışından gelen bir ustanın mühür hakk etmesi, hakkâk esnafi ile yeniden bir mücadeleye dönüştü. Sonuçta Meclis-i Vâlâ, kefil göstermek suretiyle $^{61}$ güvenilir ve ehil kişilerin de bu sanatı icra etmesine karar verdi. ${ }^{62}$ Buna rağmen gayrinizami yollarla bu işi yapan ve bu işten gelir sağlayan kişiler de vardı. Bunlar genelde merdiven altı çalışan ve belirli bir dükkâna sahip olmadıkları için de tespit edilmesi zorlaşan kimselerdi. ${ }^{63}$ Meclis-i Vâlâ'nın kararından on iki yıl sonra Hakkâk esnafı, Kethüdaları öncülüğünde hükümete bir arzuhal yazarak bu problemi yeniden gündeme getirdi. Sahte mühür vakalarında kendilerinin suçlandığı ve uyarıldığından ötürü mesleklerinin itibarının zedelendiğini ifade eden hakkâk esnafı, devletin kefalet ve liyakat üzere bu mesleğe izin

\footnotetext{
${ }^{52}$ BOA, Sadâret Mektûbî Kalemi Meclis-i Vâlâ Evrâkı (A.MKT.MVL.), 71/98.

${ }^{53}$ BOA, Sadâret Mektûbî Mühimme Kalemi Evrâkı (A.MKT.MHM.), 203/35, 21 Aralık 1860 (1277.C.7); BOA., A.MKT.MHM., 215/69.

${ }^{54}$ BOA, A.MKT.UM, 349/6, 8 May1s 1859 (1275.L.5); BOA, A.MKT.NZD, 180/93, 2 Nisan 1856 (1272.B.26); Mürur tezkerelerine vurulan sahte mühürler İstanbul Şehremaneti'nde Mürur Odası'ndaki tatbik mühür defterlerinden ortaya çıkarılmaktaydı.

${ }^{55}$ Bor Müftüsü Şakir Efendi, Niğde Müftüsü adına sahte mühür kullanarak fetva verdiğinden görevinden azledilmiş ve iki sene kadar memleketine girişi yasaklanmıştı. BOA, A.MKT., $M V L$, 93/94.

${ }^{56}$ BOA, $M V L, 269 / 10$.

${ }^{57}$ BOA, Bâb-ı Âsafî Dîvân-ı Hümâyûn Evrâkı (A.DVN.), 135/2, 15 Haziran 1848 (1264.B.13).

${ }^{58}$ Alanyalı Naib Mustafa Asım Efendi ve Ali Rıza Efendinin sahte kadılık mansıbı verdiklerine dair bkz. BOA., A.MKT.NZD., 95/98, 20 Ekim 1853 (1270.M.17)

${ }^{59}$ Bir örnek için bkz. BOA, MVL, 854/20, 20 Eylül 1863 (1280.R.6)

6011 Ekim 1859 (1276.Ra.14) tarihli bir Meclis-i Vâlâ mazbatasında şu ifadeler yer almaktadır: “...esnafin ifadesine göre hakkâk sanatında bulunacak ademler esnaf evladı olmak meşrut olarak bu da emniyet için vaz olunmus bir kaide ise de...” BOA,MVL, 830/59.

${ }^{61}$ Hakkâklık mesleğini icra edeceklerde kefil göstermek zorunlu hale gelmişti. Bir kefalet örneği için bkz. Baybura, agm, s.71.

${ }^{62}$ BOA, $M V L, 830 / 59$.

${ }^{63}$ Bir tahkikatta geçen "...merkum esnaf dâhilinde olmayıb ayakta gezerek rast geldiği yerde mühür hakk eder takımdan olduğu cihetle...” ifadeleri dikkat çekicidir. Bkz. BOA, A.MKT.MVL., 110/32, (1276. S.27).
} 
vermesinin dahi problemi ortadan kaldırmadığını, Yeni Cami, Tophane ve Beşiktaş civarlarında gayrinizami usullerle birtakım kimselerin mühür kazıdığını ve bu durumun önüne geçilmesi gerektiğini beyan etmişlerdi. ${ }^{64}$ Konuyu görüşen Şura-yı Devlet Dâhiliye Dairesi, usulsüzce mühür kazanların cezalandırılacağına dair gazetelere ilan verilmesi ve Hariciye Nezareti vasıtasıyla İran ${ }^{65}$ ve diğer ülkelerin sefaretlerinin uyarılması kararını almasına rağmen köklü bir düzenleme yapamad1 ${ }^{66} \mathrm{Bu}$ gelişme sahte evrak düzenleyenlerin evrakta kullanan mühürleri temin etmelerini kolaylaştıran bir etkiye sahipti. Zira dolandırıcılar, başta İstanbul olmak üzere sair merkezlerde sahte mühür kazıyan yahut hangi amaçla kullanılacağını soruşturmayan hakkâklardan mühür temin etmekteydiler. Dolayısıyla bu durum, Osmanlı topraklarında sahte mühür kullanımının artmasına neden olmaktaydı. Ayrıca hakkâkların hangi şartlara haiz müşteriye mühür yapacağını tayin edemeyişleri de kendilerini zan altında bırakan başlica unsurdu.

Taklit edilen mühürler çeşitli yollardan temin edilmekteydi. Bir evraka vurulan mühür yahut bir hakkâkın dükkânındaki eski bir mühür taklitte kullanılırdı. ${ }^{67}$ Mühürlerin gerçek mi sahte mi olduğunu anlamak için mühür defterlerinden istifade etmenin dışında, bu sanatta uzmanlaşmış olmak gerekmekteydi. Bir mührün gerçek mi sahte mi olduğu kolaylıkla anlaşılacak bir durum olmadığından dolandırıcılık yapmak kolaylaşmıştı. Ancak sarraflar yahut madenî işçilikten anlayan esnaf sınıfları bir mührün sahte olup olmadığını tespit edebiliyor, gerekli durumlarda örneğin evrak sahibinin k1lık-kıyafetinden şüphelenildiğinde kolluk kuvvetlerine bildirebiliyorlardı. Bu tür sahtekârlı̆̆ın yaygınlaşması özellikle sarrafların daha dikkatli olmasını gerektirmişti. Zira yukarıda tahvilde sahteciliğe örnek olarak verilen Lağımcıbaşı olayında kazdırılan mührün sahte olduğunu tahvil almaya çalışılan sarraf ortaya çıkarmıştı. Bu hadise üzerine yapılan araştırmada sahte mührün Abdülkadir adında bir hakkâka yaptırıldığı tespit edilmiş, sorguya çekilen Abdülkadir Efendi'nin böyle bir sahtekârlık olayından haberdar olmadan mührü kazıdığı anlaşılmıştır. $\mathrm{Bu}$ türlü sahtekârlıklar gayrimüslimler tarafından da yapılmaktaydı. Mesela Dersaadet’teki Bulgar kilisesinde görevli Nikola adında bir şahsın Gabrova şehrinde etrafı Bulgarca, ortası ise Türkçe yazılı mühürler yaptırarak bölgedeki muhtarlara dağıttığı ortaya çıkmıştı. ${ }^{68} \mathrm{Bu}$ gibi hadiselerin artmasında, hakkâklar ile ilgili ciddi bir düzenlemenin olmamasının usulsüzlüklere sebebiyet verdiği anlaşılmaktadır.

Gayrinizami yollarla temin edilen mühürler İstanbul ve taşradaki Osmanlı idarecileri ile kolluk kuvvetleri tarafından tespit edildiğinde, durum ilkin Dersaadet'e bildirilerek nasıl bir cezai işlem uygulanacağı sorulurdu. ${ }^{69}$ Merkezde bu tür işlere tevessül edenler Zabtiye Meclisi tarafından tevkif edilir, muhakemesi ise Şura-yı Devlet'e kadarki süreçte Meclis-i Vâlâ'da yapılırdı. Ayrıca ceza konusunda Zabtiye Meclisi'nin herhangi bir kararının olmaması ve konuyu üst makamlara taşıması da ayrıca dikkat çekicidir. 1861 yılından itibaren yeni düzenlemeler neticesinde evrakta/mühürde sahtecilik olayları Zabtiye Nezareti bünyesinde görev yapan Meclis-i Tahkik tarafindan incelenerek Meclis-i Vâlâ'nın Muhakeme Dairesi'ne havale edilirdi. Burada gerekli dava işlemleri yapıldıktan sora karar için Meclis-i Vâlâ yönetimine arz edilirdi. ${ }^{70}$ Padişah'ın iradesi ile de nihai karar verilmiş olurdu. Hakkâk esnafinı

\footnotetext{
${ }^{64}$ BOA, ŞD, 2864/13, 24 Ocak 1872 (1288.Za.13).

${ }^{65}$ Esnaf, özellikle İran'dan gelen ustalardan şikâyetçi idi.

${ }^{66} \mathrm{BOA}, S D, 2864 / 13$.

${ }^{67} \mathrm{BOA}, A . M K T$., $M V L$., $71 / 98$.

${ }^{68}$ BOA, A.MKT., MVL., 129/38, 8 Temmuz 1861 (1277.Z.29).

${ }^{69}$ Örnek bir muamele için İzmir Muhassılı'nın arızasına bkz. BOA, A.MKT., 102/66, 27 Kasım 1847 (1263.Z.18).

${ }^{70}$ BOA, MVL, 854/20; BOA, A.MKT.MHM, 215/69.
} 
kontrol altında tutan ve sorumlu oldukları kurum ise diğer esnaf birimlerinde olduğu gibi İstanbul Şehremaneti idi.

1858 y1lına kadarki süreçte evrak/mühür sahteciliği hakkında göreceli cezai işlemler uygulanmakla birlikte, Tanzimat döneminde 9 Ağustos 1858 tarihinde yürürlüğe giren Ceza Kanunu'nda evrakta sahteciliğe de yer verilmiş olup kanunun 148, 150, 154 ve 155 . maddeleri bu konuyla alakalıdır. ${ }^{71} 148$. maddeye göre Devlet emirlerini, devlet memurlarının sahh ve imzalarını ve mühürlerini değiştiren, taklit eden ve ettiren ile sahte mühür yapan ve yaptıran kişiler 10 seneden aşağı olmamak üzere kürek veya kalebentlik cezasına çarptırılacaktı. 150. madde ise şu şekildeydi: ${ }^{72}$

"Her nev'i emtia ve eşya üzerine devlet-i aliyye nâmina olarak basilmă̆a mahsus olan ve gerek bir me'muriyete ve gerek devletin ruhsatiyla olan bir şirkete veyahud bir ticaret evine mahsus bulunan her nev'i mühür ve damga ve nişanlara taklid veyahud o makule sahte damga ve nişanlart isti'mal eyleyen kimse üç sene habs ile mücazat olunur ve bu sahtekârlı̆ğndan dolayı vâki' olan zarar kendisine tazmin etdirilir ve her kim bu misillû mühür ve damga ve nişanların asıllarını ber-takrib ele geçirib de gerek hükûmet ve me'mûriyetlerin ve gerek bir cemiyet-i ticâretin ve bunların emsâli heyet ve şirket-i mahsûsânın menfaâtine muzarrır olacak halde isti'mal eyler ise altı aydan bir seneye kadar habs ile te'dib kllınır ve bu sûretle vâki' olan zarar dahi ol kimseye tazmin etdirilir"

154. maddeye göre bilerek sahte evrak kullanalar yedi seneyi aşmamak suretiyle pranga cezasına veya kalebendliğe çarptırılmıştır. 155. maddeye göre de bir şahsa ait olan evrak üzerinde sahtekârlık yapanlar veya bu şekilde bilerek sahte evrak kullananlar bir senden üç seneye kadar hapis ile cezalandırılmıştır. Aynı kanunun $45 .{ }^{73}$ ve 150 . maddeleri ${ }^{74}$ de bu maddeler ile ilişkilendirilerek ceza uygulanmıştır. Yine 45. maddedeki "bir cürmün müşterek failleri kanunun serahati olmayan mevadda ol cürmün fail-i müstakili gibi mücazat olunur" 75 hükmü gereğince evrakta ve mühürde sahtekârlık yapanların işbirlikçileri de ilgili cezaya çarptırılabilmekteydi. Mesela Drama eski kaymakamının zevcesinin alacaklı olarak evrakta benzer bir sahtekârlığa maruz kalması üzerine bu cürmü işleyen de işbirlikçisi de aynı cezaya, birer yıl hapse mahkûm edilmiştir. ${ }^{76}$

\subsection{Tanzimat Döneminde Mühür Kullanımı ile İlgili İki Önemli Hadise: Mehmed Emin Ali ve Damat Mehmed Ali Paşaların Tatbik Mührü Davaları}

Resmi ve hususi evrak üzerindeki mühürleri tahlil etmek işi o dönemde oldukça zor bir işti. Örneğin Halet Efendi'nin iki mühür kullandığı ve kendisine gelen ricacıları başından savmak maksadıyla, kaleme aldığı rica mektuplarını muhatabının nazar-1 dikkate almaması için birinci mühür ile mühürlediği, samimiyetle yazdığ1 mektuplarda ise ikinci mührü kullandığı rivayet edilmektedir. ${ }^{77} \mathrm{Bu}$ örnek, her ne kadar spesifik bir örnek olsa da, mevzunun çok nazik bir tarafının olduğunu göstermek için yeterlidir. Resmi yazışmalardaki mühürleri, ilgili evrak ve konunun ele alınması hususu aşağıdaki hadiselerde daha iyi anlaşılacaktır.

\footnotetext{
${ }^{71} 1858$ Ceza Kanunu'na bkz. Düstûr, I. Tertip, I, İstanbul 1289, s. 537-596. Adı geçen maddelerden 148. madde eserin 569-570 sayfasında, diğerleri 571. sayfasındadır.

72 Düstûr, s.570.

73 45. Madde şu şekildedir: "bir cürmün müssterek failleri kanunun sarahati olmayan mevadda ol cürmün fail-i müstakili mücazat olunur” Düstûr, s.545.

${ }_{74}^{74}$ Düstûr, s.570. 150. Maddeye göre bir cezalandırma işlemi için bkz. BOA, A.MKT.MVL, 129/38.

${ }^{75}$ Düstûr, s.545.

${ }^{76}$ BOA, A.MKT.MHM., 203/35.

${ }^{77}$ Sertoğlu, agm, s.745.
} 
Tanzimat döneminde iki Tanzimat paşasının isminin karıştığı ve tatbik mührüne başvurulan iki önemli olay yaşanmıştır. Bunlardan birincisi, 1858 Ceza Kanunu'ndan önce hicri 1268 'de cereyan eden ve Ali Paşa'nın şahsi mührü taklit edilerek tanzim edilen sahte evraktır. Bahsi geçen bu olay şu şekilde cereyan etmiştir. ${ }^{78}$ Tırhala Sancağının Kardiça Kazasından Hüseyin adlı bir zat, Hacı Ahmet Ağa adlı birinden aldığı iki sahte emirname ile kendisinin Kardiça Kaza Müdürü, kardeşinin de aynı bölgede Kırserdarı olması için İstanbul'a gelerek bazı girişimlerde bulunur. Bu esnada yine Tırhala Sancağı'na bağlı olan Golos Kazası'ndan olan ve Golos Kaymakamlığı'na atanmak için birtakım faaliyetlerde bulunan Talat Efendi ile görüşür. Talat Efendi'nin vasıtasıyla Hacı Ahmet Ağa adında benzer amaçlar taşıyan bir başka kişiyle ünsiyet kurar. Ahmet Ağa'nın destekleriyle Bab-1 Seraskeri Nizamiye Yoklama Odası kâtiplerinden Nizami Efendi'ye sahte evrak hazırlatır. Hadisenin bundan sonraki kısmında evraka sahte bir mühür vurulması gerekmektedir ki bu işi de Ahmet Ağa halleder. Hakkâklar Kethüdası Azmi Efendi'nin yanına giden Ahmet Ağa, bazı kişilerin referansıyla ve taşraya göndermek suretiyle Esseyyid Mehmed Emin Ali yazılı bir mühür kazdırır. Ancak işleme konulan evrakın üzerindeki sahte mühür, faillerin yakayı ele vermesine neden olur. Bâbıâli bürolarınca tespit edilen bu sahtekârlık olayı üzerine derhal inceleme başlatılır. Öncelikle Zabtiye Meclisi'nde sorgulamaları yapılan bu kişiler hakkındaki dosya Meclis-i Vâlâ'ya sunulur ve nihayetinde Padişah'ın da iradesi ile Talat ve Hüseyin Efendi ile Hacı Ahmed Ağa birer seneliğine Rodos adasına sürgün edilir. Evrakları yazan Nizami Efendi ise olaydan bihaber olduğu anlaşıldığından sorgulama sürecindeki hapsi kâfi görülerek serbest bırakılır. Ayrıca Hakkâklar Kethüdası'na verilen talimat $^{79}$ gereği yüksek rütbeli devlet adamlarının isimleri ile eskiden beri kullandıkları mühürlerine benzeyen mühür kazımaları

HISTORY STUDIES

195

Volume 9

Issue 4

November 2017 yasaklanır. Görülüyor ki yüksek rütbeli devlet adamlarının resmi evrakta sadece isimlerinin yazıldığ1 mühür kullanmaları taklit edilme ihtimalini artırmaktadır. Zira Fuat Paşa'nın mühürlerde makam adının da kullanılması yönündeki uygulamasının isabetli bir karar olduğu bu hadiseden anlaşılmaktadır.

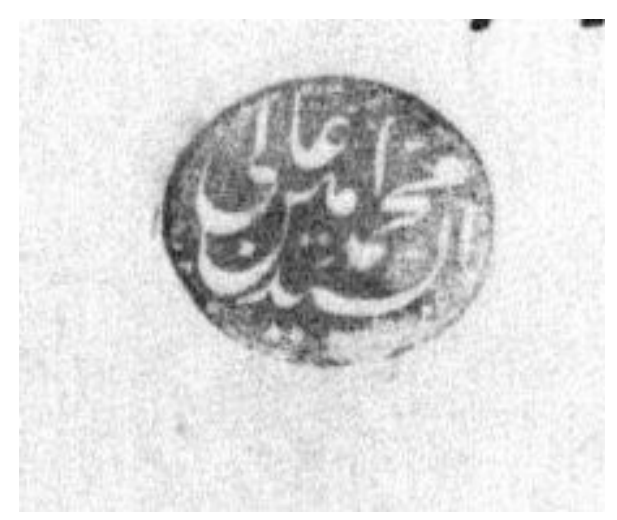

Ali Paşa adına kazdırılan sahte mühür

(BOA, I.MVL, 266/10140)

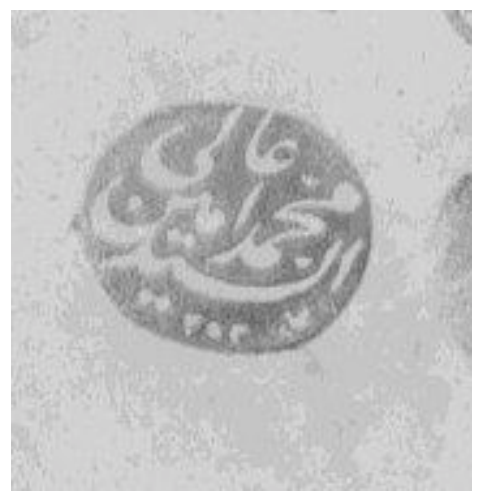

Ali Paşa'nın gerçek mührü

(BOA. Irâde Meclis-i Mahsûs

(I.MMS), 132/5650)

İkinci hadise ise Sultan Abdülmecid'in kız kardeși ile evli olan Damat Mehmed Ali Paşa'nın adının karıştığı Tatbik Mührü Hadisesidir. Bu olay, sahte evrak düzenlemekten

\footnotetext{
${ }^{78}$ İlgili yazışmalar için bkz. BOA, İrâde Meclis-i Vâlâ (İ.MVL.), 266/140.

${ }^{79}$ BOA, I.MVL, 266/140, 14 Mart 1853 (1269.C.3) tarihli irade.
} 
ziyade tatbik mührüne başvurulan bir olay olduğundan konumuz açısından önemlidir. İddiaya göre sarraf Cezayirlioğlu Mıgırdiç'in evrakı içinde Paşa'nın mührü olan 3 tahvil bulunmuştu. Bu tahviller Paşa'nın Mıgırdiç'ten rüşvet aldığına delil olarak gösterilince Mehmed Ali Paşa mühürlerin sahte olduğunu iddia etmiştir. Ancak paşaya yönelik suçlamaların dinmemesi üzerine mesele Meclis-i Vükelâ'ya intikal etmiştir. Meclis, gerekli tahkikatın yapılması için yeni kurulan Meclis-i Tanzimat'ı görevlendirmiştir. ${ }^{80}$

Meclis-i Tanzimat, mührün mahiyetini ortaya çıkarmak için ehl-i hibreye ${ }^{81}$ başvurarak incelemeye tabi tutulacak 3 esas belirledi. Bunlar; mührün kaide-i hattı yani yazıs1, kaide- $i$ hendesesi yani şekil ve ölçüleri ve san'at-ı hakk yani işçiliği idi. ${ }^{82}$ Uzman kişiler tarafindan yazı ve şekil itibariyle incelenen mühürlerin aslına uygun olduğu kanaatine varılmışsa da san'at-ı hakk yönünden bazı şüphelerin ortaya çıkması üzerine yukarıdaki üç açıdan yeniden incelenmesine karar verildi. Hat sanatındaki maharetlerinden ötürü Meclis-i Vâlâ üyelerinden İzzet Efendi, Takvimhane-i Amire memurlarından Raci Efendi ve Abdülfettah Efendi meclise davet edildi. İlgili tahvillerdeki mühürler ile Paşa'nın sair resmi yazışmalarından numune olarak alınan mühürler karşılaştırılarak yeniden incelendi. İzzet ile Raci Efendiler her iki mührün tamamen aynı olduğu görüşünde iken Abdülfettah Efendi tahvillerin birindeki mühürde "Mehmed" isminin ikinci mim harfi ile "seyyid" kelimesindeki sin harfinin biraz kırık olduğu ancak bunun mührün basılışından kaynaklanmış olabileceğini belirterek mühürlerin ölçülmesi durumunda bu şüphenin de ortadan kalkacağını ifade etti. Bunun üzerine mühürlerin şekil ve ölçü bakımından incelenmesi için bir mühendis ile Sikkezenbaşı Şaban Efendi görevlendirildi. Bu incelemede mühürlerin birbirinden farksız olduğu kanaati hâsıl olunca mühürler son olarak Hakkâk esnafından Azmi, Salih, Vefa, Hüsnü ve Said Efendilere gösterildi. Ancak Hakkâkların uzun süren incelemelerinden sonra aralarında bazı ihtilaflar oluştu. Meclis, bu hakkâklarla bir oturum daha gerçekleştirip tespitlerini daha gerçekçi ve çelişkisiz bulduğu Hüsnü Efendiye mühürlerin aynı olduğu teyit ettirip sonra diğer hakkâkların da ittifakını sağladı. Nihai rapor Sarraf Mıgırdiç’in tahvillerindeki mühürlerin Damat Mehmed Ali Paşa'ya ait olduğuna dair hazırladığı raporu ${ }^{83}$ hükümete sunan Meclis-i Tanzimat'ın görevi böylece bitmiş oldu. ${ }^{84}$

Görüldüğü gibi sahte mühür kullanımı veya evraktaki mührün sahteliği/gerçekliği durumları ahali ve alt tabakadaki memurlar için söz konusu olduğunda adi bir mesele olarak değerlendirilmiştir. Bu tür adi olaylar yargı organlarınca kısa sürede çözüme kavuşturulmuştur.

\footnotetext{
${ }^{80}$ Son derece komplike olduğu anlaşılan bu hadise, esasında Mustafa Reşid Paşa ile Damat Mehmed Ali Paşa arasındaki siyasi bir çekişmeydi. Hadisenin patlak vermesinden önce Mehmed Ali Paşa'nın sadaretinde de aynı iddiayı, yani Cezayirlioğlu'ndan rüşvet aldığını, kendisi Mustafa Reşid Paşa'ya karşı ileri sürmüştü. İngiltere ve Fransa temsilcilerinin de siyasi arka planında yer aldığı bu meselenin etraflı bir şekilde incelendiği şu çalışmaya bkz. Serap Sunay, "Tanzimat Meclisi'nde Görülen İlk Rüşvet Davası: Tatbîk-i Mühür Meselesi ve Perde Arkası”, Türk Kültürü Incelemeleri Dergisi, Sayı: 33, İstanbul 2015, s. 85-112.

${ }^{81}$ Mührün, üzerinde adı yazılı kişi tarafından kendine ait olmadığı iddia edildiğinde yahut sahte olduğu şüphesi söz konusu olduğunda bilirkişi makamında hakkâklardan ve devlet görevlilerinden oluşan komisyonlar kurulması zaman zaman başvurulan bir yöntemdir. Böyle bir uygulamaya ihtilafa düşüldüğünde veya çok önemli hadiselerde başvurulurdu. Benzer bir dava için bkz. Baybura, agm, s.72.

${ }^{82}$ BOA, A.MKT, MVL, 70/96, 22 Şubat 1855 (1271.C.4).

${ }^{83}$ BOA, A.MKT, MVL, 70/96; bu tahkikatı yürüten Meclis-i Tanzimat üyeleri arasında Mehmed Rüşdi, Yusuf Kamil, Mehmed Emin Ali, Fuad, İbrahim Ethem, Sadık Rıfat ve Saffet Paşalar gibi Tanzimat ricalinden önemli simalar vardır. Damat Mehmed Ali Paşa bütün bu tahkikatların sonucunda Sultan Abdülmecid tarafından Kastamonu'ya sürgün edilmiş, ancak hemen ardından affedilmiştir. Cevdet Paşa, Tezâkir, Haz.: Cavid Baysun , TTK Yayınları (3.Bask1), I, Ankara 1991, s.37-39.

${ }^{84}$ Reşid Paşa'nın bilirkişi incelemeleri esnasında yaptığı müdahaleler, davanın sağlıklı bir şekilde yürümediğini göstermektedir. Bkz. Sunay, agm, s.102,103 vd. Bu çalışma tatbik mühürlerinin Osmanlı diplomatikasındaki yerini teknik boyutları ile incelediğinden, bahsi geçen hadisenin diğer boyutları üzerinde durulmamıştır.
} 
Ancak yüksek rütbeliler söz konusu olduğunda çok hassas davranılarak hususi komisyonlarca uzun süreli tetkiklerle değerlendirilmeler yapılmıştır.

\section{Sonuç}

$\mathrm{Bu}$ çalışmada şekil yönünden incelenen resmi belgenin önemli bir unsuru olan mühür, birkaç farklı açıdan ele alınmıştır. Bunlar; Mühürlerin Osmanlı Diplomatik ilmindeki yeri, mühürcülük sanatı, sahte mühür kullanmak suretiyle evrakta sahtecilik olayı ve Osmanlı Devleti'nin sahteciliğe karşı aldığı tedbirler olarak suralanabilir. Böylece Osmanlı diplomatikasında mühür kullanımının mahiyeti ve ortaya çıkan sorunlar irdelenmeye çalışılmıştır.

Klasik dönem Osmanlı diplomatiğindeki katı ve detaycı kurallar, devlet ve kurumları ile halk arasındaki münasebeti somutlaştıran belgelerin/yazışmaların daha sorunsuz bir şekilde icra edilmesini sağlarken, merkezi idarenin zayıflamaya başlaması, sahte resmi evrak düzenlemek suretiyle çıkar sağlamak isteyen bazı çevreleri cesaretlendirmiştir. $\mathrm{Bu}$ vasıtalarından biri olan sahte mühür kullanımının yaygınlaşması, şüphe yok ki esnaf/lonca teşkilatının zayıflaması ile birlikte gelişmiştir. Yukarıda teferruatlıca bahsedilen 19. yüzyıldaki hadiseler bu durumu kanıtlar niteliktedir. Görüldüğü üzere devleti dolandırmaya tevessül edenlerin, ihtiyaç duydukları sahte mührü tedarik etme hususunda pek bir zorluk çekmemişlerdir. Tanzimat Fermanı'nın ilanı ile bürokratik alanda da hızı bir dönüşüm geçiren Osmanlı Devleti'nde geleneksel diplomatik kaidelerin uygulanmasında zafiyetler ortaya çıkmıştır. Zira evrakın sahihliğini gösteren "sahh" uygulamasının kaldırılması ve tatbik mühür defterlerine ancak gerektiğinde başvurulması, Osmanlı bürolarına gelen evrakın gerçekliği hususunda şüpheleri artıran bir etkiye sebep olmuştur. Ali Paşa gibi üst düzey bir yöneticinin mührünün taklit edilmesi, bu zafiyetin bir neticesi olarak yorumlanabilir. Ayrica bu bürokratik dönüşüm ile devletin kurum sayısı ile bu bürolarda çalışan memur sayısının kıyaslanamayacak derecede artması da buna bir gerekçe olarak değerlendirilmeye müsaittir. Diğer taraftan devlet görevlilerinin resmi evrakta şahsi mühürlerini kullanmaları, Osmanlı diplomatik kurallarının bir diğer zafiyet noktasıdır. Nitekim Fuat Paşa döneminde bu konuda önemli bir adım atılarak mühürlerde kişi adları ile işgal ettiği makam birlikte gösterilmeye başlanmıștır. Bunun haricinde 1858 yılındaki Ceza Kanunu'na kadarki süreçte sahte evrak/mühür kullandığı tespit edilen kişilere uygulanan cezaların görecelik arz etmesi, adaletin tesisi açısından eleştirilecek bir husus olmasına mukabil dönem itibariyle resmi evrakta sahteciliğin yaygınlaşmasında rol oynamıştır. Nitekim 1858 Ceza Kanunu'nun 4 maddesinin bu hususa ayrılması devletin kanunlaştırma sürecindeki evrak ve mühürde sahteciliğin bir problem olarak görülmesinin kanıtı niteliğindedir.

Son olarak Tatbik Mühür Defterleri'ne dikkat çekmekte fayda vardır. Bu defterler, Osmanlı Devleti'nin son dönemine kadar düzenli olarak tutulan ve Osmanlı diplomatiği için önemli kaynaklardandır. Osmanlı tarih araştırmacıları, devlet görevlilerinin tespiti başta olmak üzere birçok hususta bu defterlerden istifade edebileceği gibi mühür defterleri, özellikle belge incelemelerinde karşılaştırmalı bir yöntem için başvurulabilecek önemli bir envanter olarak değerlendirilmelidir. 


\section{Kaynaklar}

\section{Başbakanlık Omanlı Arşivi (BOA):}

Ali Emiri Mustafa III (AE, SMST.III), nr: 179/14117.

Bâb-ı Âsafì Dîvân-ı Hümâyûn Evrâkı (A.DVN.): nr: 135/2.

Cevdet Iktisad (C.IKTS.): nr: 25/1227.

Hatt-ı Hümâyûn (HAT): nr: 1313/51167.

Irâde Meclis-i Mahsûs (İ.MMS): nr: 132/5650.

Irâde Meclis-i Vâlâ (İ.MVL.): nr: 266/140.

Meclis-i Vâlâ Evrâkı (MVL.): nr: 459/79, 830/59, 269/10, 854/20, 166/7.

Sadâret Mektûbî Kalemi (A.MKT.): nr: 102/66.

Sadâret Mektûbî Kalemi Meclis-i Vâlâ Evrâkı (A.MKT.MVL.): nr: 110/32, 93/94, 71/98, 129/38, 110/32, 70/96.

Sadâret Mektûbî Kalemi Nezâret ve Devâir Evrâkı (A.MKT.NZD.):nr: 91/99, 180/93, 95/98.

Sadâret Mektûbî Kalemi Umûm Vilâyât Evrâkı (A.MKT.UM.): nr: 349/6, 446/54.

Sadâret Mektûbî Mühimme Kalemi Evrâkı (A.MKT.MHM.): nr: 215/69, 203/35, 215/69, $203 / 35$.

Şûrâ-yı Devlet (ŞD), 2864/13.

Topkapı Sarayı Müzesi Arşivi (TS.MA.): Defter (d.) nr: 9784.

Yıldız Esas Evrakı (Y.EE), nr: 78/141.

Resmi Yayınlar:

Düstûr, I. Tertip, I, İstanbul 1289.

\section{Eserler-Makaleler-Ansiklopedi Maddeleri}

AKYILDIZ, Ali, Tanzimat Dönemi Osmanlı Merkez Teşkilâtında Reform (1836-1856), Eren Yayınları, İstanbul 1993.

, Osmanlı Bürokrasisi ve Modernleşme, İletişim Yayınları, İstanbul 2009.

AYDIN, Bilgin - Keskin, İshak, "Osmanlı Bürokrasisinde Evrak Sahteciliği, Diplomatik ve Diplomatika Eğitimi”, Osmanlı Araştırmaları Dergisi, XXXI, İstanbul 2008, ss. 197-228.

BAYBURA, İbrahim Kemal, "Osmanlılarda Mühür”, Topkapı Saray Müzesi Yıllık II, İstanbul 1987, ss.69-85.

BAYRAM, Sadi, "Vakıflar Genel Müdürlüğü Arşivinde Bulunan 1783-1810 Yılları Arasında İşlem Görmüş Bir Mühür Tatbik Defteri”, III.Uluslararası Türk Kültürü Kongresi Bildirileri Ankara 25-29 Eylül 1993, Hz.: Alev Kahya Birgül, Atatürk Kültür Dil ve Tarih Yüksek Kurumu, Ankara 1999, ss.304-315. 
BOZCU, Pelin (Filiz), Osmanlı Sarayında Sanatçı ve Zanaatçi Teşkilatı Ehl-i Hiref, (T.C. Kültür Bakanlığı Kültür Varlıkları ve Müzeler Genel Müdürlüğü Yayımlanmamış Uzmanlık Tezi), İstanbul 2010.

CANDEMIR, Murat, Bâb-ı Âli Evrâk Odast, (İstanbul Üniversitesi Sosyal Bilimler Enstitüsü Tarih Anabilim Dalı Yayımlanmamış Doktora Tezi), İstanbul 2002.

CEVDET PAŞA, Tezâkir, Haz.: Cavid Baysun, TTK Yayınları (3.Baskı), I, Ankara 1991.

Evliya Çelebi Seyahatnâmesi, C.1, 1. Kitap, Hz.: Robert Dankoff, Seyit Ali Kahraman, Yücel Dağl1, Yapı Kredi Yayınları, İstanbul 2011.

GÖKBİLGIN, M.Tayyib, Osmanlı Paleografya ve Diplomatik İlmi, Enderun Kitabevi, İstanbul 1992.

HAMMER, Osmanlı Mühürleri, (Çev:Ümit Öztürk), Pera Yayınları, İstanbul 1999.

İNALCIK, Halil, "Osmanlı Bürokrasisinde Aklâm ve Muâmelât”, Osmanlı Araştırmaları I, İstanbul 1980, ss.1-14.

İPŞİRLİ, Mehmet, "XVI. Asrın İkinci Yarısında Kürek Cezası İle İlgili Hükümler", İstanbul Üniversitesi Edebiyat Fakültesi Tarih Enstitüsü Dergisi, Say1:12, 19811982, ss.203-248.

Istanbul Esnaf Tarihi, C.I, Haz.: Ahmet Tabakoğlu, Ahmet Kal'a, Salih Aynural, İsmail Kara, İstanbul 1997.

KÜTÜKOĞLU, Mübahat, “Diplomatik”, DIA, C.9, 1994, ss.364-366.

, “Mühür”, DİA, C.31, 2006, ss.530-531.

, Osmanlı Belgelerinin Dili (Diplomatik), TTK Yayınları, 3. Baskı, Ankara 2013.

MERSIOWSKY, Mark, "Ausweitung der Diskurszone um 1700. Der Angriff des Barthélémy Germon auf die Diplomatik Jean Mabillons”, içinde Thomas Wallnig, Thomas Stockinger, Ines Peper, Patrick Fiska (Hg.), Europäische Geschichtskulturen um 1700. Gelehrsamkeit, Politik und Konfession, Berlin 2012, ss. 447-484.

PAKALIN, Mehmet Zeki, Tarih Deyimleri ve Terimleri Sözlüğü, C.I, Milli Eğitim Basımevi, İstanbul 1971.

SERTOĞLU, Mithat, "Kaybolan Bir Türk Sanatı Mühürcülük”, Resimli Tarih Mecmuası, C.VII/12, İstanbul 1956, ss.741-745.

SUNAY, Serap, “Tanzimat Meclisi’nde Görülen İlk Rüşvet Davası: Tatbîk-i Mühür Meselesi ve Perde Arkası", Türk Kültürü İncelemeleri Dergisi, Sayı: 33, İstanbul 2015, ss. 85-112.

UZUNÇARŞILI, İ.Hakkı, Osmanlı Devletinin İlmiye Teşkilâtı, TTK Basımevi, 3. Baskı, Ankara 1988.

, "Tuğra ve Pençeler ile Ferman ve Buyuruldulara Dâir", Belleten, C.V/1718, Ankara 1995, ss.101-144.

"Osmanlı Devleti Zamanında Kullanılmış Mühürler Hakkında Bir Tetkik", Belleten, C.IV/16, 1940, ss.495-544. 


\section{Ekler}
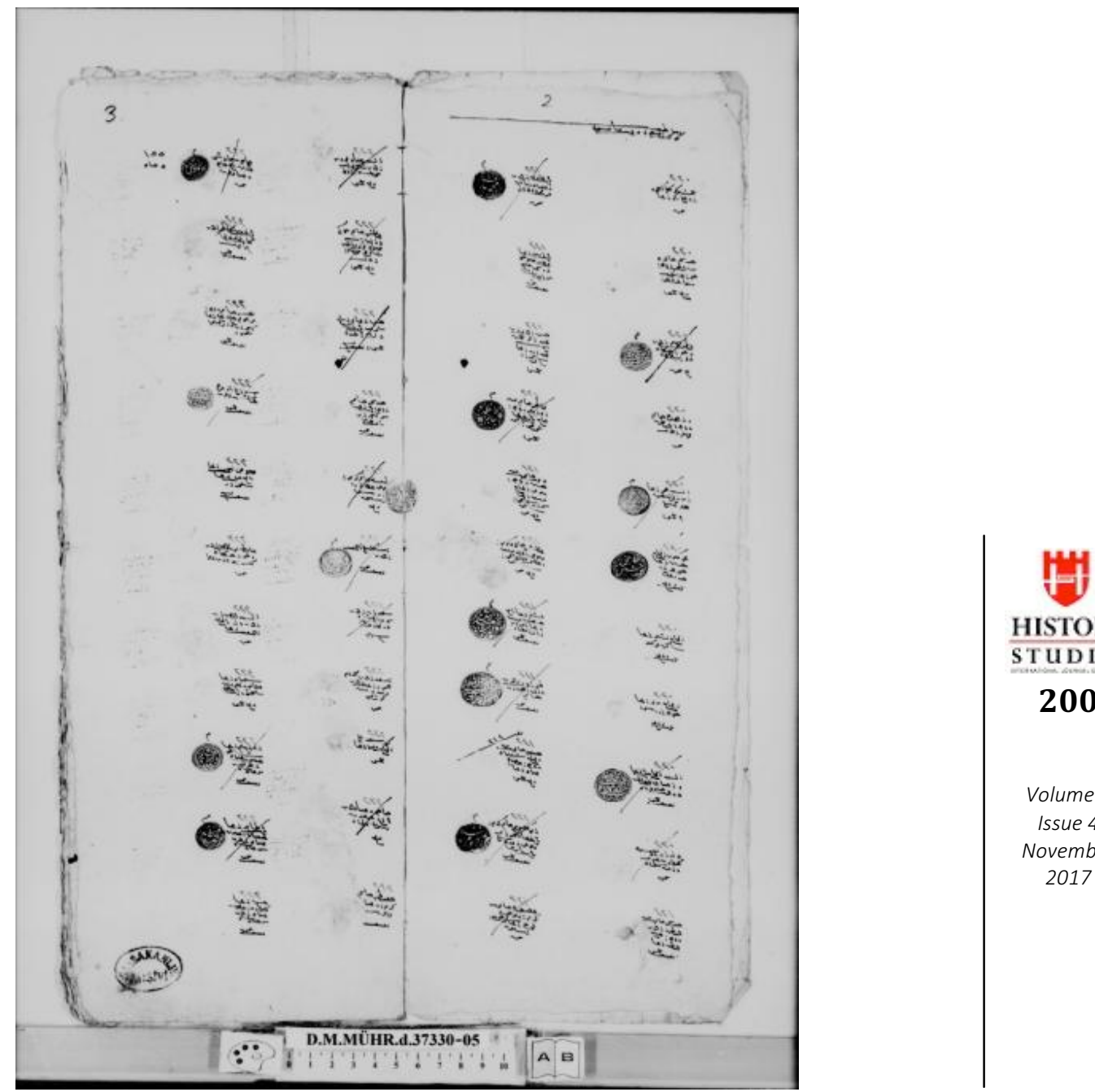

HISTORY

STUDIES

200

Volume 9

Issue 4

November

2017

Ek 1: Mühür tatbik defterlerinden örnek bir varak (BOA, D.M. MÜHR.d, 37330-5) 


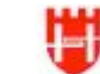

HISTORY STUDIES

201

Volume 9

Issue 4

November

2017

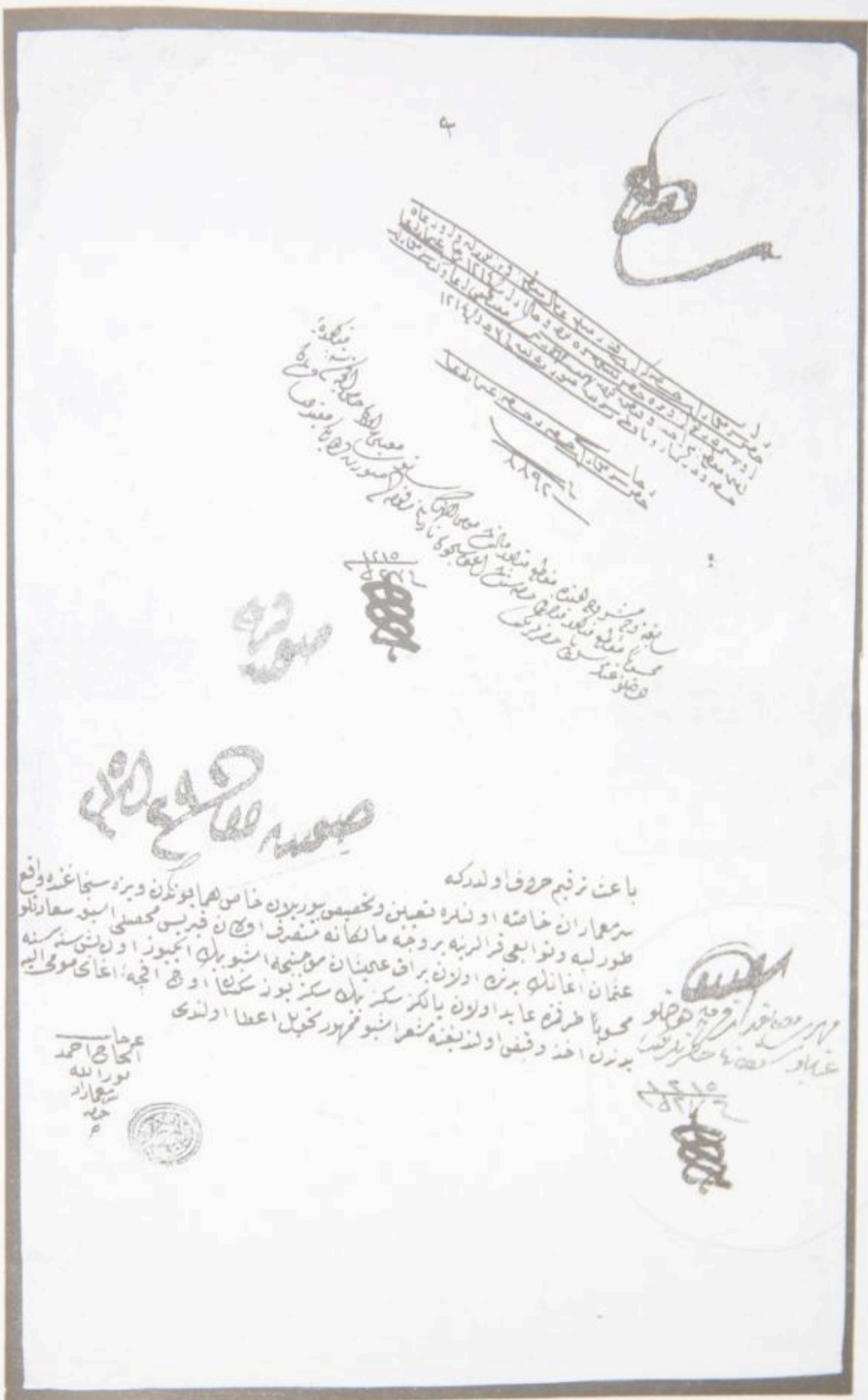

$-133$

Memhur tahvil

(Cev-M, nr. 20180)

Ek 2: Mührü tatbik edilmiş bir tahvil (Kütükoğlu, Osmanlı Belgelerinin Dili, s.567) 


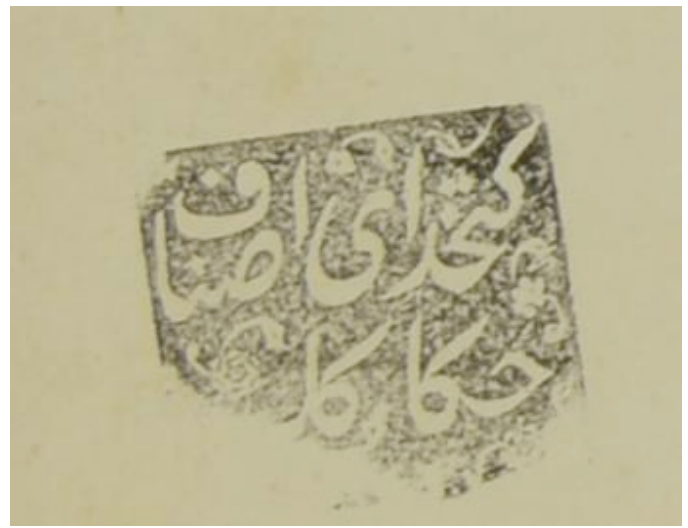

Ek 3: XIX. yüzyıl sonlarında Hakkâklar Kethüdası'nın kullandığı resmi mühür (BOA, ŞD, 2864/13)

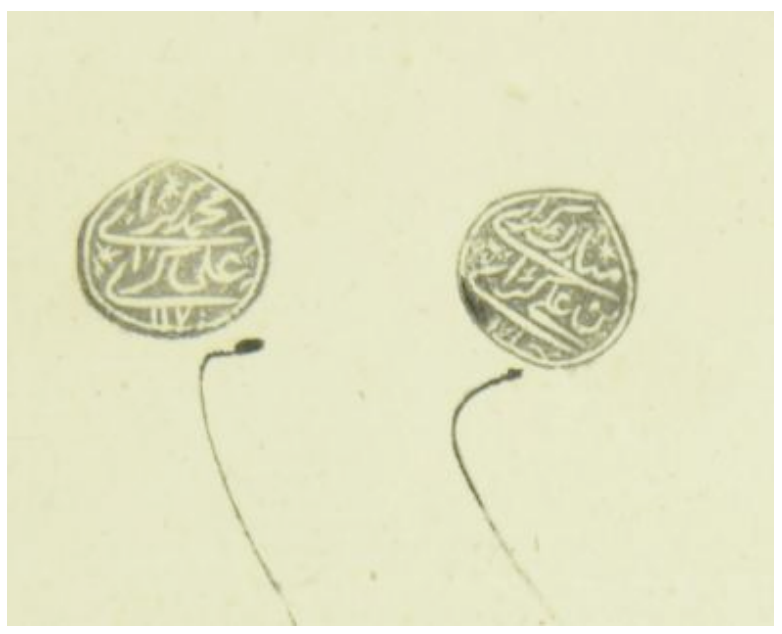

Ek 4: Mehmed ve Mübarek Girayların tatbik mühürleri (BOA, AE. SMST.III, 179/14117) 